\begin{tabular}{|l|l|l|}
\hline \multicolumn{2}{|c|}{ PublisherInfo } \\
\hline \hline PublisherName & $:$ & BioMed Central \\
\hline \hline PublisherLocation & $:$ & London \\
\hline \hline PublisherImprintName & $:$ & BioMed Central \\
\hline \hline
\end{tabular}

\title{
Worms reveal intron insights
}

\begin{tabular}{|l|l|l||}
\hline \multicolumn{2}{|c|}{ ArticleInfo } \\
\hline \hline ArticleID & $:$ & 4972 \\
\hline \hline ArticleDOI & $:$ & $10.1186 /$ gb-spotlight-20040630-01 \\
\hline \hline ArticleCitationID & $:$ & spotlight-20040630-01 \\
\hline \hline ArticleSequenceNumber & $:$ & 35 \\
\hline \hline ArticleCategory & $:$ & Research news \\
\hline ArticleFirstPage & $:$ & 1 \\
\hline \hline ArticleLastPage & $:$ & 3 \\
\hline \hline & & RegistrationDate : 2004-6-30 \\
\hline ArticleHistory & $:$ & OnlineDate \\
\hline \hline ArticleCopyright & $:$ & BioMed Central Ltd2004-6-30 \\
\hline \hline ArticleGrants & $:$ & \\
\hline \hline ArticleContext & $:$ & 130595511 \\
\hline \hline
\end{tabular}


Irish researchers have discovered 122 novel introns that appeared in the genomes of Caenorhabditis elegans and Caenorhabditis briggsae since the two species diverged80 to 120 million years ago, shedding light on how new introns arise and are subsequently spread among genes.

The genomes of both worms contain roughly 100,000 introns, of which more than 6000 are unique to one species or the other. Kenneth Wolfe and Avril Coghlan identified 81 new introns in C. elegans and 41 new introns in C. briggsae (Proc Natl Acad Sci USA 2004, DOI: 10.1073/pnas.0308192101) . Of these, 13 are found in genes implicated in premRNA processing, the authors report in the June 28 Proceedings of the National Academy of Sciences USAearly online edition.

"We used BLAST [Basic Local Alignment Search Tool] to identify orthologous genes across all the species (animal and nematode), and by comparison of all genes, we were able to find intron sites present in one of the nematodes, but absent in all other species," Wolfe, from Trinity College Dublin, told us. "We therefore inferred that these gained introns must be less than 100 million years old."

Their results represent two major findings, said John Logsdon, an evolutionary biologist at the University of Iowa. One of these is the finding that introns are changing a lot, both in terms of gain and loss. "The more incredibly novel part, is that this is some of the first evidence of how one intron can give rise to another," he said. Even more significant is the fact that the authors used actual sequence data to infer the process by which introns were gained, rather than relying on phylogenetic arguments, the conventional approach to studying intron evolution, he added.

Just where these novel introns had settled in the worm genomes was evidenced by a stretch of DNA called an exon splice site consensus sequence. "With these new introns, the consensus sequence is stronger than the consensus sequence around any of the other introns," said Wolfe. "This suggests that this splice site was the target site these new introns were inserted into. We verified this to be true."

Their findings help provide answers to ongoing controversy over where introns come from. "It's very significant since it goes to the heart of the debate about the discovery of introns - have they always been around or have they been added to the genome recently," Michael Purugganan, an evolutionary geneticist at North Carolina State University in Raleigh, told us. "What this paper shows, very nicely, is that there is evidence that certain introns have been gained very recently. It gives credence to the notion that organisms can gain introns in their genes."

"It's considered very important to find very young newborn introns just inserted into a gene," said Eugene Koonin, a computational biologist at the National Center for Biotechnology Information in Bethesda, Md. "These researchers seem to be presenting the youngest ones detected [to date]. It's potentially important because you can look at features of these introns and compare how they differ from older ones."

So far, similar studies in mammals have failed to detect evidence of any new introns. Bacteria, on the other hand, lack introns altogether, leading scientists to wonder if they were lost from bacteria early on in their evolution. 
Two unusual findings in the latest study, according to Wolfe, were the discovery of copies of introns elsewhere within the same genome and duplicate copies of an intron within the same gene. The authors attribute the anomalies to a process called reverse splicing, whereby an excised intron somehow inserts into a different site within the same mRNA template. Reverse transcription of the mRNA then gives rise to DNA containing the reinserted intron, becoming part of the genome.

But Koonin is not entirely convinced of this conclusion. "What I'm less enthusiastic about is the likely mechanism [proposed by the authors] of the insertion of these new introns," he said. "They specifically claim reverse splicing of preexisting introns in the same or other genes. I find the evidence insufficient on that count."

The problem is that similarity between new introns always includes repetitive sequences. "The authors see that and claim that is evidence of common origin," Koonin said. Purugganan agreed, "It's not an easy mechanism to invoke in this case."

"We'll learn more if we try to detect even younger introns by analyzing them from plants and other organisms," added Koonin.

\section{References}

1. Holding C: Caenhorabditis comparative genomics Genome Biology, November 17, 2003., [http://genomebiology.com/researchnews/default.asp?arx_id=gb-spotlight-20031118-02]

2. Kenneth H. Wolfe, [http://wolfe.gen.tcd.ie]

3. Proceedings of the National Academy of Sciences USA, [http://www.pnas.org]

4. BLAST, [http://www.ncbi.nlm.nih.gov/BLAST/]

5. John M. Logsdon, Jr., [http://euplotes.biology.uiowa.edu/web/jml.html]

6. Michael D. Purugganan, [http://www.cals.ncsu.edu/genetics/purugganan/purugganan.html]

7. Eugene V. Koonin, [http://www.ncbi.nlm.nih.gov/CBBresearch/Koonin/]

This PDF file was created after publication. 